\title{
A Theological Economy in the Parable of the Sheep and Goats (Mt 25:31-46)
}

\author{
Deborah Doyinsola Adegbite ${ }^{1}$, Olusola Deborah Adegbite ${ }^{2}$ \\ ${ }^{1}$ Adeleke University, Ede, Nigeria \\ ${ }^{2}$ Bethel Institute of Theology \& Biblical Research, An Affiliate of Olabisi Onabanjo University, \\ Gbongan, Nigeria \\ Email: adegbitedebbie@yahoo.com
}

Received 30 March 2015; accepted 15 April 2015; published 20 April 2015

Copyright (C) 2015 by authors and OALib.

This work is licensed under the Creative Commons Attribution International License (CC BY). http://creativecommons.org/licenses/by/4.0/

\section{(c) (i) Open Access}

\begin{abstract}
This paper explores an economic system that is based on theological rationale to see whether the difficulties that Nigerians (Africans) face in developing can be viewed from a theological stand point. It uses the Parable of the Sheep and Goats recorded only in Matthew's Gospel to proffer solutions to the problem of underdevelopment in Nigeria by advocating for a theological economy. The methodologies used for the interpretation of this parable are hermeneutical-critical and reader-response. The results of this study show that if a theological economy is practiced as a lifestyle following the principles of theological economics as exemplified in the Parable of the Sheep and Goats, and the developing countries of the world adopt the attitude of the Sheep as against the Goats, it will give hope that Nigeria and Africa at large would experience not just development but sustainable development from now henceforth if practised if the principle is applied.
\end{abstract}

\section{Keywords}

Economic Development, Sheep, Goat, Africa, Nigeria, Poor, Hunger, Sick

Subject Areas: Economics, Sociology

\section{Introduction}

The advocation for a theological economy or an economic theology is not a new debate. Robert Nelson, Paul Oslington among others stand in the line of scholars that advocate that economics to remain in discourse with theology. St Augustine in The City of God presents in a novel fashion what a theological economy may look like where he contrasts how living in the city of God is much different from how it is in the Roman Empire. The book of Revelation describes how the New Jerusalem will be even in economic terms where the river of life and the tree therein are not just refreshing but healing and sustaining. Jesus talks of the kingdom of heaven severally 
and he mentions how people who belong to that kingdom were called to a life of service even in economical terms. Wes Howard-Brook and Anthony Gwyther in their book Unveiling Empire: Reading Revelation then and now [1] dwells on such economic topics in the light of Revelation's message. St Francis of Assisi, Mother Theresa, even Martin Luther King Jnr have ideas on how our economic lives here on earth are a function of a proper theological understanding of good living.

The parable of the Sheep and Goats recorded in Mt 25:31-46 is one that comes after a series of parables and sayings about various dimensions of the Kingdom of Heaven. Matthew alone records this parable. From chapter 24 of Matthew, there is a bulk of eschatological material and the selected text is the last of these parables and is also followed by the various events leading into the Passion Week. Being the last of these parables, it evidently occupies a unique position in Matthew's eschatological framework. This paper will focus on the parable in its original language and bring out relevant economic lessons from it to promote a sustainable development system in Nigeria and Africa at large.

\section{The Parable of the Sheep and Goats}

Matthew does not introduce this parable as he introduced the others before it in chapter 25. Those ones are introduced with "The kingdom of heaven shall be like..." however the introduction to this parable is "When the son of man comes in his glory and all the holy angels with him, then he will sit on the throne of his glory." The entree of this story paints a majestic scene, such suitable for judgement. The Son of Man is not there alone but is accompanied by the angels, the holy ones and he sits on his throne of glory. The presence of the holy angels should not be taken for granted for they stand as witnesses to the events to follow and perhaps the events that have preceded. Here, Matthew echoes many themes from Jewish thought. Unlike the two preceding parables in which there was a bridegroom and a master, here it is the majestic Son of Man echoing Daniel's visions in Daniel 7:13.

The purpose of this coming involves all the nations being gathered before him. The phraseology here in verse

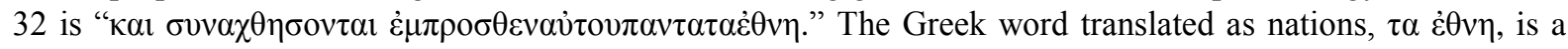
neuter plural noun in Greek and in this sentence acts as the subject of that sentence. Ordinarily, neuter plural subjects in Greek are followed by singular verbs, however, as Daniel Wallace notes, "when the author wants to stress the individuality of each subject involved in a neuter plural subject, the plural verb is used." [2]. This is to say that although nations in general would be gathered, their individuality is not lost in the collective. Each person is individually in the presence of the Son of Man going to receive justice due to them for their actions.

There is the question on the identity of $\tau \alpha \dot{\varepsilon} \theta \mathrm{v} \eta$. Are they just the gentiles or everyone? Due to the nature of the rest of the passage, one of judgment based on works, some are inclined to think that the gentiles who have not believed in Christ or saved by faith would be justified based on their works.

Before the judgement is passed however, a separation is done between the sheep and the goats. Again the

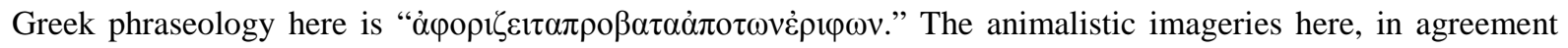
with Beare echoes Ezekiel 34. The preposition, $\dot{\alpha} \pi$ o primarily means "away from” as opposed to $\dot{\varepsilon} \kappa$ that means "out of". W. Bauer, quoted by Wallace says that "In the NT it has encroached on the domain of Att. غ̇к." [3]. Combining both ideas in understanding how this separation occurs, the Son of Man like a shepherd takes the sheep away from and/or out of the goats as two separate entities. That people live together in the world does not make them all the same; there are the sheep and the goats who shall be separated from one another. In Israelite culture, James Freeman mentions that "Sheep and goats are allowed to mingle during the day while at pasturage but at night are separated." [4].

The imagery and juxtaposition of sheep and goats bring up ideas that resonate with both Jewish and Yoruba cultures. These are well-known and commonly reared animals for various purposes. Hence to describe people using this imagery would be understood. The audience as well as we now, know that to describe a person as a goat is to say the person is stubborn and strong headed while a sheep is meek, docile, and coward-like. This quality of meekness of the sheep cannot be overemphasized in the larger context of this work.

Having separated them, the Son of Man goes on to set the sheep on the right and the goats on the left. Shepherds in the period of separation use their rods or staffs. "When a sheep came up, he tapped it with his long staff on the right side of the head, and it quickly moved off to his right; a goat he tapped on the other side and it went to his left.” [5]. In the South West of Nigeria, among the Yorubas in agreement with biblical customs, the right signifies the superior, the better thing, the appropriate place and the left signifies the opposite. Even among the 
Greeks, Beare notes that "It is natural that the Greeks should conceive that souls destined for the Elysian Fields should take the road to the right, and the souls sentenced to the pains of Tartarus should take the road to the left." [6].

Then the Son of Man, now identified as King pronounces those on the right side as blessed of the Father and calls them to come to inherit the kingdom prepared from the foundations of the world. Unlike the woman with the issue of blood (Lk 13:11ff) whose healing to Jesus was rather unexpected, so to speak, those at the right had their inheritance planned from the foundations of the world. It is not in the least surprising that the King is happy with the sheep. V.G. Tasker says "It is as a shepherd that this King will exercise His Kingship, caring for all the members of the flock... taking pity on them when they are harassed and helpless.” [7]. The sheep in this parable therefore have acted compassionately like the King would. Then, the King goes on to give evidences of how they had merited such honour.

The situations the King highlights to which those on the right responded to are the following: hunger ( $\dot{\varepsilon} \pi \varepsilon i v \alpha \sigma \alpha)$,

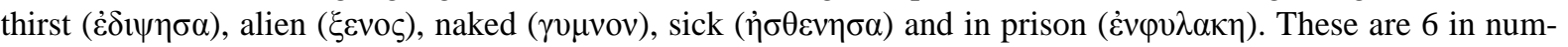
ber of which typology says is the number of man. The Greek words used in describing the situations of hunger, thirst, and sick are aorist verbs, that is, it was at one point in time when the sheep did not know that they found people in the states of hunger, thirst and sickness and in response at that point in time too, the sheep performed acts of kindness. The acts of kindness of the sheep respectively were to provide food, give a drink, take in the stranger, clothe the naked and visit the sick and imprisoned. These acts are obviously not elaborate or such that called attention to self like the Pharisees who give alms in public for the praise of men (Mt. 6:9). They saw other people in these various situations and responded positively to aid them. Interestingly, the sheep now identified as the righteous in verse 37, were surprised to now know that they have done these many good deeds. The response they get is that "inasmuch as you did it to one of the least of these my brethren, you did it to me" (verse 40). Importantly is that the characteristic of sheep earlier listed as being meek, also suggests that these acts of kindness were done with humility and willingness, with no ulterior motive that even without knowing that what they did they did to the King, they did it with an understanding that all that they have they too have received.

The recipients of their kind deeds were described as "one of the least of these my brethren". A strand of thought is to say like Benedict Green that "Christian disciples are brothers to each other." On the other hand is Beare's thought that "Here the thought is generalized... [this phrase] cannot be taken as restricted to disciples of Jesus." [8]. This is highly debated. Within the context of missionary interpretations, like John Donahue [9] the "least of my brethren" refers to the missionaries or Christian disciples who go into gentile nations. A more inclusive interpretation is that it refers to Christians in general. The problem of restricting the recipients of these kind acts to Christians raises some disturbing questions. Are non-Christians therefore not eligible to be helped by Christians (or anyone at all)? What implication does this have for Christian theology when Christians themselves have been undeserving of the grace (God's gift) to them? What human is in the position to decide if someone else, a stranger in particular was part of the "least of my brethren"? Jesus went about doing good. Why should his followers or anyone else at that be selective about who they do their good to? If it has been rightly established that the call to do good is not only for Christians to do, how much sense does it make for a non-Christian to do good to only Christians and not non-Christians?

Despite these divergences, an evidence in favour of Beare's thinking is that the sheep did not know that what they did was done to the King, this means that either the people they thought they had been kind to were not necessarily Christian or identified with the King somehow. They were the least in the community whose status could not have really mattered to the doers of kind deeds.

Then on the other hand are the goats who did not do any of the simple acts of kindness. These are cursed and cast out of the King's presence into the outer darkness meant for the devil and his angels. They too did not know what they had done, or rather what they had not done, to warrant such dejection. They are cast into eternal fire where there would be weeping and gnashing of teeth. This imagery of eternal punishment in hell makes Beare say that "Apart from the book of Revelation, the Gospel according to Matthew makes far more of the doctrine of hell as a place of eternal torment than any other book of the New Testament." [10]. Understanding of this eternal punishment is varied among scholars. Tasker sees the word eternal ( $\alpha i \omega v i o v)$ "is a qualitative rather than a quantitative word." [11]. That is it refers to the world of eternity in terms of a superior world to the present not necessarily that their punishment lasts for eternity. He however still admits that eternal fire can "indicate final destruction." [11]. However if eternal as an adjective is taken as qualitative or quantitative, it is a severe punishment that happens in the world to come, and is the severest of punishments Matthew records for offenders, a 
punishment that no one who loves themselves would wish for themselves. The severity of the crime is seen in this magnitude of their punishment though they have nevertheless unknowingly committed the sin. There is no acceptable excuse however. Ignorance is no excuse in human courts of law so also in this final judgement scene. In Tasker's assessment of this parable and the two other parables in this chapter, Matthew stresses that "The sins of omission are seen to be even more damning than the sins of commission. The door is shut against the foolish virgins for their negligence; the un-enterprising servant is cast out as a good-for-nothing for doing nothing; and those on the left hand are severely punished for failing to notice the many opportunities for showing kindness which had been given them." [12].

The aforementioned interpretation of the parable of the sheep and goats has been to highlight how seriously the King takes acts of kindness among nations (and individuals). What then is the situation of Africa that calls for such analysis?

\section{The Challenges of Development in Africa}

Adesina Olubitan recognizes that "Poverty is a very complex issue in which various causes often play a part." [13]. It is truly unfortunate as Emmanuel Asante reflects that "we can hardly narrate our story as West Africans without narrating the story of poverty and displacement." [14]. In addition to this are other problems of famine, civil wars, corruption and the like. Yet these woes are linked intrinsically though not exclusively to the colonial project, the scramble for Africa by Europe. It has been many years that African countries have gained their independence from colonial masters yet the quality of life keeps dwindling.

What possible explanations can there be for these? Slavery and exploitation that characterized the colonial rule show that human emotions of empathy were lacking. Unfortunately, religion provided justification for those cruel acts. The basis of the colonial project was founded on what Akinpelu Olutayo and Ayokunle Omobowale call the "four denials." [15]. First was the denial of history; second, a denial of science; third, a denial of poetry; and a denial of philosophy [15]. With this in the mind of the incoming colonialists, it should not be surprising that nothing African was appreciated, that Africans were described as geographically isolated, racially inferior, culturally stagnant, and psychologically backward. Colonialism was therefore business oriented in hopes of bringing light into the Dark Continent with untapped resources, a trade that ended up benefiting Europe than it profited the working Africans. After independence the means of production still remained as it had been designed by the colonial masters, "the means of production were not indigenously developed." [16]. Nnamdi Azikwe's thoughts included that "Colonialism... interrupted normal African development, and forced backwardness on the technologically less advanced natives." [17].

Yet despite that "African theories of underdevelopment are inextricably linked with the concepts of imperialism and colonialism" [18], one must not settle for the convenient position of blaming African under development problems only on the Europeans for colonizing Africa. This would even also be a one-sided assessment. Obafemi Awolowo's understanding was that "there were three imperialisms reigning side by side and in concert." [19]. According to Awolowo, the first is the Imperialism of ignorance, disease and want; the second, was the British colonialism; the third is the imperialism of local rulers that benefited from the British imperialism. Although the British colonialism is long ended now, the other two imperialisms still remain according to Obafemi Awolowo's analysis. The latter of these imperialisms of local rulers that benefited from the British imperialism has graduated now to what we see in politics, where the few control the bulk of the nation's wealth and recklessly lavish the nation's wealth as though it were a personal property. The idea of local imperialism even dates to before the colonial project of local rulers thirsting after dominion at the expense of innocent lives and bloodshed.

These are just few of the problems that hinder development in Nigeria. The list is endless. However, the parable of the Sheep and Goats offers a comprehensive solution that addresses the problem at its roots.

\section{Reflections}

As it is, the rich get richer and the poor get poorer; the rich get richer at the expense of the poor. The problem therefore is not the absence of wealth but rather with its distribution and circulation.

A very major issue needs to be addressed if Nigeria would move forward, and develop in a sustainable manner, if poverty would be alleviated, if anybody's life would get better. This issue is: if the poor countries/people would be uplifted, the lifestyle of the richer countries/people would be inherently affected. The rich cannot be 
rich if there are no poor to compare them with. These tensions can be readily seen if one studied the problems with the abolishment of African slavery, how it became difficult to balance "In Christ... there is no slave or free" (Gal 3:28) and the great economic gains from slave labour.

Yet what does the parable of the Sheep and Goats teach people today in how to respond to Nigeria's plight of underdevelopment?

The parable mentions various categories of people: the hungry, thirsty, stranger, naked, sick and imprisoned. Each of these accurately readily describes a majority of Nigerians. There is this picture on social media that talks of how Gari (Cassava flakes) has saved more lives than the Red Cross. This testifies to the levels of starvation that Gari, a very cheap food (often viewed as a food for the poor) helps to alleviate. Several radio health and nutrition talks call attention to how unhealthy it is for people to eat a majorly carbohydrate meal. A particular speaker mentioned how back in the days when almost everyone had farms, the heavy carbohydrate meals that characterized Nigerian meals were compensated by fruits harvested freely from farms but these fruits are now more difficult to access thereby lowing the average quality of food. Access to good food is limited or expensive.

Thirst characterized the second group of beneficiaries of the Sheep. Publicities often talk of how access to clean and safe water is a problem in many rural areas. This might not be a problem to indigenous people as an adage even says that "Dirty water does not kill." But this was before the outbreak of Cholera. The point however is that though it might not be so obvious, there are actually places where access to clean and safe water might be a problem due to lack of borehole, infested rivers, scarcity of water during dry season. The condemnation of the goats as noted earlier was because they failed to recognize persons in need of such help.

The term "stranger" or "foreigner" or "alien" describes the third category of people mentioned in the parable. Many African peoples have experienced displacement; internal displacement within their country or displacement that meant leaving the country of origin. This includes the Rwandans during the genocide, the Liberians during the civil war, the depopulation of African countries during the slave trade, the Ghanaians during crises, Northern Nigerians due to Boko Haram and religious crises and countless groups of people on a smaller scale. Fortunately on one hand is that many African cultures value hospitality to strangers to protect them from waylayers and natural nocturnal harm. Unfortunately, on the other hand, is that, this quality is getting lost in the whole modernization, civilization and neo-colonial scheme. It becomes difficult to entertain strangers whether in public or in private. The harsh economic conditions have made certain people want to take advantage of "the gullible" to steal from them or attack them.

Being naked is a function of displacement as well as poverty. In modern terms, it might not necessarily be physically completely naked people, the naked person could as well be that person wearing their only dress, an ancient-of-days looking suit and shoes whose fronts look up to the heavens for a change.

Sickness is an inevitable aspect of human life. It is not human caused hence the prerogative here is not necessarily to prevent it. The King here recognizes this. The King did not even expect them to heal the sick because the King knows that it ultimately remains in his jurisdiction ultimately to heal. The King however requires that the sick get care from people who are truly caring. The psychology of wellbeing includes having support from loved ones and a sick person keeping a positive attitude to life without these hardly would treatments work as effectively as they should on the long run.

Despite that some say "It is, however, addressed primarily to the 'nations', the Gentiles, who though ignorant of the Law of God have it written in their hearts." [20]. "In this final judgement scene there is surprisingly little that is specifically Christian.” [21]. The ideas of saving faith, justification through faith is missing rather the salvation of the righteous has been through their works. Then no one, regardless religion is left out in what the King demands from all people for which he separates the sheep and goats. The social problems in our community must be addressed with very practical solutions that necessarily not need be elaborate.

These problems range from problems human face as a result of nature, poverty, human wars, natural disaster, legal systems (of justice or injustice that imprison people). In the recommendations of this parable therefore no one is supposed to be hungry, thirsty, naked, homeless, or lonely even if in prison or sick. The solutions thereby provided also serve to address the psychological challenges of loneliness, physical mortality of the sick, social degradation of the stranger and the economic calamity of the hungry and thirsty. C. M. Sugden says that, "How a community treats its poor is, for the Bible, the acid test of life." [22]. In a similar light, Olubitan notes that we need to "articulate ways of how best to carry the values of our faith in the midst of this appalling poverty situation; to love our neighbours, pursue peace and social justice in everyday's choice and commitment.” [23]. It is an exam to be written with the humility of the sheep with all innocence, no ulterior motive, and no eye service. 
This is a test that each person must endeavour to pass. When each person plays their own little role, like the words of the poem below, these little kind deeds would make the earth an Eden like heaven above. This is a theological economy where those who are truly human will take time to do just a little more than they are mandated to do by virtue of their position or situation and all must be done putting others first. A song by Fanny Crosby, a blind hymn writer who was talking to a group of working men requested if there was a boy at the meeting who had wandered away from home that such should come to her at the end of the service. To this request, came forward a young man of eighteen and asked her, “Did you mean me?” Whereas, a few days earlier, Fanny Crosby had been given the suggestion to write a hymn based on Luke 14:23, the parable of the Great Feast, where the master asked his servants to bring unworthy people to replace those who thought they are too important to honour the invitation. The theme of the hymn is "Rescue the Perishing, care for the dying," and on returning home from the mission trip, she wrote:

1) Rescue the perishing, care for the dying, snatch them in pity from sin and the grave; weep over the erring one, lift up the fallen, tell them about Jesus, the mighty to save.

\section{Ref:}

Rescue the perishing, care for the dying; Jesus is merciful; Jesus will save.

2) Though they are slighting Him, still He is waiting, waiting the penitent child to receive; plead with them earnestly, plead with them gently. He will forgive if they only believe.

3) Down in the human heart, crushed by the tempter, feelings lie buried that grace can restore; touched by a loving heart, wakened by kindness, chords that are broken will vibrate once more.

4) Rescue the perishing, duty demands it strength for thy labour the Lord will provide; back to the narrow way patiently win them, tell the poor wanderer a Saviour has died.

This song shows the kind of heart that everyone should have in order to promote a theological economy that would pay attention to the marginalized in the society and inevitably develop the economy. The poem below by Isaac Watts, mentioned earlier and titled "Kind Deeds" also explains the point, a theological economy where those that have much do not have too much and those with little do not have too little.

Little drops of water

Little grains of sand

Make the mighty ocean

And the pleasant land

Thus the tiny minutes

Humble though they be

Make the mighty ages

Of eternity

Little deeds of kindness

Little words of love

Make this earth an Eden

Like heaven above

\section{References}

[1] Howard-Brook, W. and Gwyther, A. (1999) Unveiling Empire: Reading Revelation Then and Now. Orbis Books, New York.

[2] Wallace, D. (1996) Greek Grammer: Beyond the Basics. Zondervan, Michigan, 400.

[3] Wallace, D. (1996) Greek Grammar: Beyond the Basics. Zondervan, Michigan, 368.

[4] Freeman, J. (1996) The Manners and Customs of the Bible. Whitaker House, New Kensington, 379.

[5] Bible Centre (2004) Bible Manners and Customs of the Bible, 222. www.ntslibrary.com

[6] Beare, F.W. (1981) The Gospel According to MATTHEW. Basil Blackwell, Oxford, 494.

[7] Tasker, V.G. (1961) The Gospel According to Matthew. Tyndale Press, London, 21.

[8] Beare, F.W. (1981) The Gospel According to Matthew. Basil Blackwell, Oxford, 495.

[9] Donahue, J. (1966) The "Parable" of the Sheep and the Goats: A Challenge to Christian Ethics. Theological Studies, 47, 
26.

[10] Beare, F.W. (1981) The Gospel According to Matthew. Basil Blackwell, Oxford, 496.

[11] Tasker, V.G. (1961) The Gospel According to Matthew. Tyndale Press London, 240.

[12] Tasker, V.G. (1961) The Gospel According to Matthew. Tyndale Press London, 239.

[13] Olubitan, A. (2014) Poverty Alleviation Programmes in Nigeria: A Christian Perspective. In: Akanni, A.A., et al., Eds., Religion, Peace and Development in Nigeria, A Festschrift in Honour of Prof E. Ade Odumuyiwa, A Publication of the Department of Religious Studies, Olabisi Onabanjo University, Ago-Iwoye, 32.

[14] Asante, E. (2000) Root Causes of Poverty and Displacement in West Africa: The Gospel, Poverty and the Displaced in Africa: The Case of the West African Sub-Region. In: Martey, E. and Nwagwu, M.G., Eds., Proceedings of West African Association of Theological Institutions (WATTI), 20.

[15] Olutayo, A. and Omobowale, A. (2007) Capitalism, Globalization and the Underdevelopment Process in Africa. Africa Development, 32, 100.

[16] Olutayo, A. and Omobowale, A. (2008) Capitalism, Globalization and the Underdevelopment Process in Africa. Africa Development, 32, 104.

[17] Grundy, K.W. (1966) African Explanation to Underdevelopment: The Theoretical Basis for Political Action. The Review of Politics, 28, 63.

[18] Grundy, K.W. (1996) African Explanation to Underdevelopment: The Theoretical Basis for Political Action. The Review of Politics, 28, 62.

[19] Grundy, K.W. (1996) African Explanation to Underdevelopment: The Theoretical Basis for Political Action. The Review of Politics, 28, 66.

[20] Green, F.W. (1953) The Gospel According to Matthew. Clarendon, Oxford, 238.

[21] Beare, F.W. (1981) The Gospel According to Matthew. Basil Blackwell, Oxford, 496.

[22] Sugden, C.M.N. (1988) New Dictionary of Theology. Edited by Sinclair Ferguson and David F. Wright, IVP, Leceister, 523.

[23] Olubitan, A. (2014) Poverty Alleviation Programmes in Nigeria: A Christian Perspective. In: Akanni, A.A., et al., Eds., Religion, Peace and Development in Nigeria, A Festschrift in Honour of Prof. E. Ade Odumuyiwa, A Publication of the Department of Religious Studies, Olabisi Onabanjo University, Ago-Iwoye, 38. 